\title{
Assessment of selected adipocytokines in obese women with postmenopausal osteoporosis
}

\author{
Joanna Głogowska-Szeląg, Beata Kos-Kudła, Bogdan Marek, Mariusz Nowak, Lucyna Siemińska \\ Department of Pathophysiology and Endocrinology, Medical University of Silesia, Zabrze, Poland
}

\begin{abstract}
Introduction: Osteoporosis and obesity are considered civilisation diseases. Menopause is a time of increased bone resorption and increased mass of adipose tissue. Adipocytokines secreted by the adipose tissue are believed to be a potential factor in the pathogenesis of osteoporosis. Material and methods: The aim of this research was to assess leptin, adiponectin, and resistin secretion in obese postmenopausal women with osteoporosis and determine whether obesity might be a factor mitigating the risk of osteoporosis. The study involved 80 postmenopausal women with osteoporosis divided into groups: I with BMI of 30.0-34.9, obese; and II with BMI of 18-24.9, normoweight. Leptin, adiponectin and resistin concentrations were assessed, and bone mineral density (BMD) was measured in the L1-L4 section of the spine using the DXA densitometric method.

Results: The results of the comparison of the two groups indicate a statistically significant dependence in groups regarding leptin secretion; the group of obese women demonstrated significantly higher concentrations. No differences between the groups were demonstrated for adiponectin or resistin secretion.

Conclusions: Higher leptin concentration and a positive correlation with BMI was confirmed in obese postmenopausal women with osteoporosis. It was also demonstrated that BMD increases with growing BMI. No effect of obesity on the secretion of adiponectin or resistin in women with postmenopausal osteoporosis was found. From among the investigated adipocytokines, only leptin can be considered a bone tissue protective factor in postmenopausal women. (Endokrynol Pol 2019; 70 (6): 478-483)
\end{abstract}

Key words: adipocytokines; obesity; osteoporosis; women; menopause

\section{Introduction}

The continuously increasing average length of life in modern societies and lifestyle changes bring about new problems and challenges to contemporary medicine. One of them is osteoporosis (OP) - the most common metabolic disease of bones [1-3] with a $40 \%$ risk of bone fracture in women over 50 years old, presently considered as a civilisation disease [4]. The hypoestrogenism that accompanies menopause accelerates bone resorption, causing increased bone turnover, negative balance, and microarchitecture changes. The bones become more brittle and susceptible to fractures [4, 5]; this mainly concerns cancellous bone. Approximately $25 \%$ of cancellous bone tissue and $15 \%$ of compact bone tissue are lost [5], so the recommended densitometric test in the spine area in that group of women is the first to reveal osteoporosis. Post-menopausal hormonal changes may cause a fatty tissue weight gain. It is known that low body weight is an important risk factor of low bone mass and increased bone resorption [6]. Even though the fatty tissue and the bone tissue fulfil different functions, it is believed that excessive fatty tissue may protect bones and decrease the risk of osteoporosis [7-10]. A short time ago, fatty tissue was still viewed as an inactive energy reservoir [11], but nowadays it is seen as an endocrine organ [8]. The endocrine activity consists of participation in the metabolism of sex steroids and secretion of biologically active protein substances called adipocytokines, the endocrine activity of which is both local and systemic $[8,11]$. The fatty tissue also exerts a diverse influence on the bone tissue [7, 11, 12]. It is believed that adipocytokines belonging to peptides may play a role in the pathogenesis of osteoporosis [11] due to their common origin: the mesenchymal tissue [7]. Bone metabolism is influenced by body weight and the fatty tissue content in the body $[2,8,9]$, and the growth of these two parameters may increase bone mass [7].

Recent discussions concern the possibility of applying cytokines in osteoporosis therapy [7] because leptin and adiponectin have a wide range of pathogenetic actions [11]. In post-menopausal women, adipocytokine secretion and concentrations fluctuate [14]. The stimulating effect of leptin on bone tissue metabolism [15] is partially explained by discovering its receptors on osteoblasts and chondrocytes [16]. The increased 
bone mass in obesity may stem from hyperleptinaemia, which inhibits the differentiation of osteoclasts and stimulates that of osteoblasts [8], causing an increase of bone mass volume and density. Researchers point at the beneficial effect of leptin (depending on the BMI and the body fat mass) on bones in women of various ages [16]. In obesity, there is central resistance to leptin as well as a beneficial peripheral effect of leptin on bones [17]. Osteoblasts synthesise leptin, and its concentrations fluctuate during the cell differentiation process. Leptin stimulates proliferation of osteoblasts, bone mineralisation, and collagen synthesis [18]. It also increases OPG concentration (which is beneficial to the bones) in relation to RANKL, inhibiting RANKL production and bone resorption [8], and it exerts an anti-resorptive action in vivo [19]. The prevailing opinion is that leptin stimulates bone growth (an increase in length and thickness) via osteogenesis and angiogenesis only in the early period of life; in later years, it weakens bone turnover by activating the OPG-RANKL system [8]. It is indicated that leptin concentration in blood serum correlates with BMI and depends on the total mass of the fatty tissue and the percentage content of fat in the body [8]. Adiponectin increases tissue sensitivity to insulin, and plays a significant role in the metabolism of lipids and glucose. Its concentration in obese persons is lowered, and the body mass increase causes its further drop [20, 21]. Reports concerning the influence of adiponectin on the bone tissue show that it promotes bone formation [8] via stimulation of osteoblasts, influencing the proliferation and differentiation processes by increasing the expression of alkaline phosphatase, osteocalcin, and type I collagen [22]. It increases BMD by inhibiting the activity and differentiation of osteoclasts from CD14 ${ }^{+}$monocytes [23] and has a mitogenic action on osteoblasts [8]. According to certain researchers [24], adiponectin influences BMD independently. It is suggested that adiponectin exerts an unfavourable influence on bone mass because it increases resorption by stimulating RANKL and inhibiting the expression of osteoprotegerin, which intensifies osteoclastogenesis [24]. The fatty tissue becomes the main source of oestrogens in menopause, so women with low BMD demonstrate hypoestrogenism and high adiponectin concentrations.

Certain literature data [11] reveal the correlation between resistin concentration, fatty tissue mass, and insulin resistance; on the other hand, they do not confirm that finding [25]. Few studies report the influence of resistin on bone tissue. In vitro tests have revealed stimulation and proliferation of osteoblasts and differentiation of osteoclasts [26]. The role of resistin in humans is not fully known, and the research results are divergent and controversial [27].
The conviction that obesity lowers the risk of osteoporosis is based on clinical observations showing that obese persons usually have normal or slightly elevated BMD in lumbar spine (L2-L4), proximal femoral epiphysis, and proximal radial epiphysis, in comparison with persons with normal or low body weight [8-10, $12,28-30]$. Certain authors actually highlight that body weight is the main factor determining BMD and fracture risk, and that the fatty tissue plays the fundamental role in this relationship [8]. Researchers have demonstrated the existence of a correlation between BMI and BMD $[10,28]$, but not all of them agree on the presence of those relations.

The basis of diagnosing osteoporosis in post-menopausal women is BMD evaluation. Dual-X-ray absorptiometry (DXA) is a densitometric test constituting a recognised standard in this respect. It forms the basis for diagnostic and therapeutic decisions, depicts the fracture hazard, and allows one to assess treatment results and make a differential diagnosis. A test conducted in the lumbar section of the spine forecasts the risk of all osteoporotic fractures very effectively [31]. In recent years, we have witnessed an increasing social and economic burden in the form of two significant problems: the enormous spread of obesity worldwide and a high percentage of persons suffering from osteoporosis due to society aging. The aim of this research was an assessment of leptin, adiponectin, and resistin secretion in obese post-menopausal women with osteoporosis, and an attempt to explain whether obesity might be a factor decreasing the risk of osteoporosis development in post-menopausal women.

\section{Material and methods}

The examinations covered 80 post-menopausal women diagnosed with osteoporosis after risk factor analysis and a densitometric test. The patients were divided into two study groups of 40 women each. The first group included post-menopausal women with osteoporosis and a body mass index (BMI) of 30-34.9, which met the criterion of obesity.

The second group included post-menopausal women with osteoporosis and a body mass index (BMI) of 18-24.9, which fell within the normal range.

Every examined woman underwent anthropometric measurements. The body weight was measured on medical scales with an accuracy of $100 \mathrm{~g}$. The height was measured in a free-standing position using an anthropometer; the examined woman's head was positioned in the eye-ear (Frankfurt) plane with an accuracy of $0.1 \mathrm{~cm}$. Each measurement was carried out three times, and the obtained average was used in the study. The BMI (body mass index) was calculated using the following formula: $\mathrm{BMI}=$ body weight $[\mathrm{kg}] /$ height $[\mathrm{m}] 2$. Bone mineral density (BMD) was measured in the L1-L4 section of the spine using the DXA densitometric method. The criterion of diagnosing osteoporosis was the value of BMD $\left[\mathrm{g} / \mathrm{cm}^{2}\right]$ determined by the $\mathrm{WHO}$, and the T-score measure was used. The tests were conducted using the Lunar DPX (GE, USA) device, which underwent routine standardisation according to ISCD recommendations. The measurement error (CV\%) of BMD in the spine did not exceed $1.5 \%$ (confidence level: $80 \%$ ). 
The peripheral blood for biochemical assays $(5 \mathrm{~mL})$ was drawn from the ulnar vein between 8:00 and 9:00 am, on an empty stomach, after a night rest of at least eight hours. The examined women were treated in the Rheumatological Clinic and the Osteoporosis Treatment Clinic. Serum samples after blood centrifugation with a speed corresponding to $1000 \mathrm{~g}$ for 15 minutes were put into test tubes and frozen at a temperature of $-70^{\circ} \mathrm{C}$ until the assay day.

Adipocytokines in the blood were marked using the immunoenzymatic method ELISA using commercial assays. The within-run errors and the external errors did not exceed $10 \%$.

The statistical analysis was conducted using Statistica 10.0, StatSoft Inc. The analysed parameters were compared between the groups using parametric and non-parametric tests. The goodness of fit of the distribution of the studied variables in comparison with normal distribution was assessed using the Shapiro-Wilk test. The comparisons between the groups utilised the Mann-Whitney U test. The correlation analysis was carried out using the Spearman's rank correlation coefficient. The assumed significance level was $\alpha=0.05$. The statistically significant results were those for which the calculated probability value was $\mathrm{p}<0.05$.

\section{Results}

The participating obese postmenopausal women with osteoporosis had an average leptin concentration of $24.53 \pm 17.29 \mathrm{ng} / \mathrm{mL}$. (Tab. I) Leptin concentrations were lower in women with normal BMI and reached $15.87 \pm 15.96 \mathrm{ng} / \mathrm{mL}$. (Tab. II) The groups exhibited a statistically significant difference in leptin concentration. (Tab. I) A multiple comparison procedure (Dunn's post-hoc) demonstrated a statistically significant difference between the group with normal BMI and the group of obese women; the level for this pair was $\mathrm{p}=0.0034$. Leptin concentrations in blood decrease as the BMI decreases. The comparative analysis confirmed a positive, statistically significant relationship $(\mathrm{r}=0.31$; $p=0.0006$ ) between leptin level and BMI in the whole investigated population of postmenopausal women with osteoporosis (Fig. 1).

The highest levels of adiponectin were found in the group with normal BMI, reaching $31.69 \pm 27.91 \mu \mathrm{g} / \mathrm{mL}$. (Tab. II) The group of obese women demonstrated a lower concentration of adiponectin compared to the group with normal BMI. The levels in the former group were $25.08 \pm 19.37 \mu \mathrm{g} / \mathrm{mL}$. No statistically significant difference between the groups was found (Tab. II).

The investigated groups of postmenopausal women with osteoporosis demonstrated similar levels of blood resistin. The lowest resistin concentrations were noted in the group of obese women. The average value was $10.58 \pm 4.63 \mathrm{ng} / \mathrm{mL}$. The average level in the group with normal BMI was slightly higher and reached $10.79 \pm 4.71 \mathrm{ng} / \mathrm{mL}$. Based on possible links between bone tissue and adipose tissue, the investigated adipocytokines were analysed in terms of dependence on the BMI. No such relationship was identified (Tab. III, IV).

The correlation analysis demonstrated a statistically significant $(\mathrm{r}=0.18, \mathrm{p}=0.0498)$ positive relationship; increasing BMD entailed increasing BMI.

\section{Discussion}

The issue of obesity is particularly noticeable in postmenopausal women. The concentration of leptin in healthy people exhibits a positive correlation with the $\mathrm{BMI}$ and adipose tissue content. A higher leptin level

Table I. Investigated parameters in the obese group

\begin{tabular}{|c|c|c|c|c|c|c|}
\hline Variable & $\mathbf{N}$ & Mean & Median & Minimum & Maximum & SD \\
\hline Leptin [ng/mL] & 40 & 24.53 & 20.17 & 0.23 & 83.35 & 17.29 \\
\hline Adipo $[\mu \mathrm{g} / \mathrm{mL}]$ & 40 & 25.08 & 19.37 & 7.32 & 71.34 & 16.49 \\
\hline Resistin [ng/mL] & 40 & 10.58 & 9.20 & 3.56 & 23.82 & 4.63 \\
\hline BMI $\left[\mathrm{kg} / \mathrm{m}^{2}\right]$ & 40 & 31.48 & 30.79 & 30.02 & 34.68 & 1.52 \\
\hline $\mathrm{BMD}\left[\mathrm{g} / \mathrm{cm}^{2}\right]$ & 40 & 0.82 & 0.85 & 0.51 & 0.97 & 0.10 \\
\hline
\end{tabular}

$\mathrm{BMI}$ — body mass index; BMD — bone mineral density; SD — standard deviation

Table II. Investigated parameters in the group with normal body mass index (BMI)

\begin{tabular}{|c|c|c|c|c|c|c|}
\hline Variable & $\mathbf{N}$ & Mean & Median & Minimum & Maximum & SD \\
\hline Leptin [ng/mL] & 40 & 15.87 & 11.04 & 1.94 & 95.20 & 15.96 \\
\hline Adipo $[\mu \mathrm{g} / \mathrm{mL}]$ & 40 & 31.69 & 23.88 & 2.38 & 140.83 & 27.91 \\
\hline Resistin [ng/mL] & 40 & 10.79 & 10.31 & 4.19 & 25.44 & 4.71 \\
\hline BMI [kg/m²] & 40 & 22.01 & 22.31 & 18.13 & 23.83 & 1.51 \\
\hline BMD $\left[\mathrm{g} / \mathrm{cm}^{2}\right]$ & 40 & 0.79 & 0.84 & 0.56 & 0.90 & 0.11 \\
\hline
\end{tabular}

BMD — bone mineral density; SD — standard deviation 


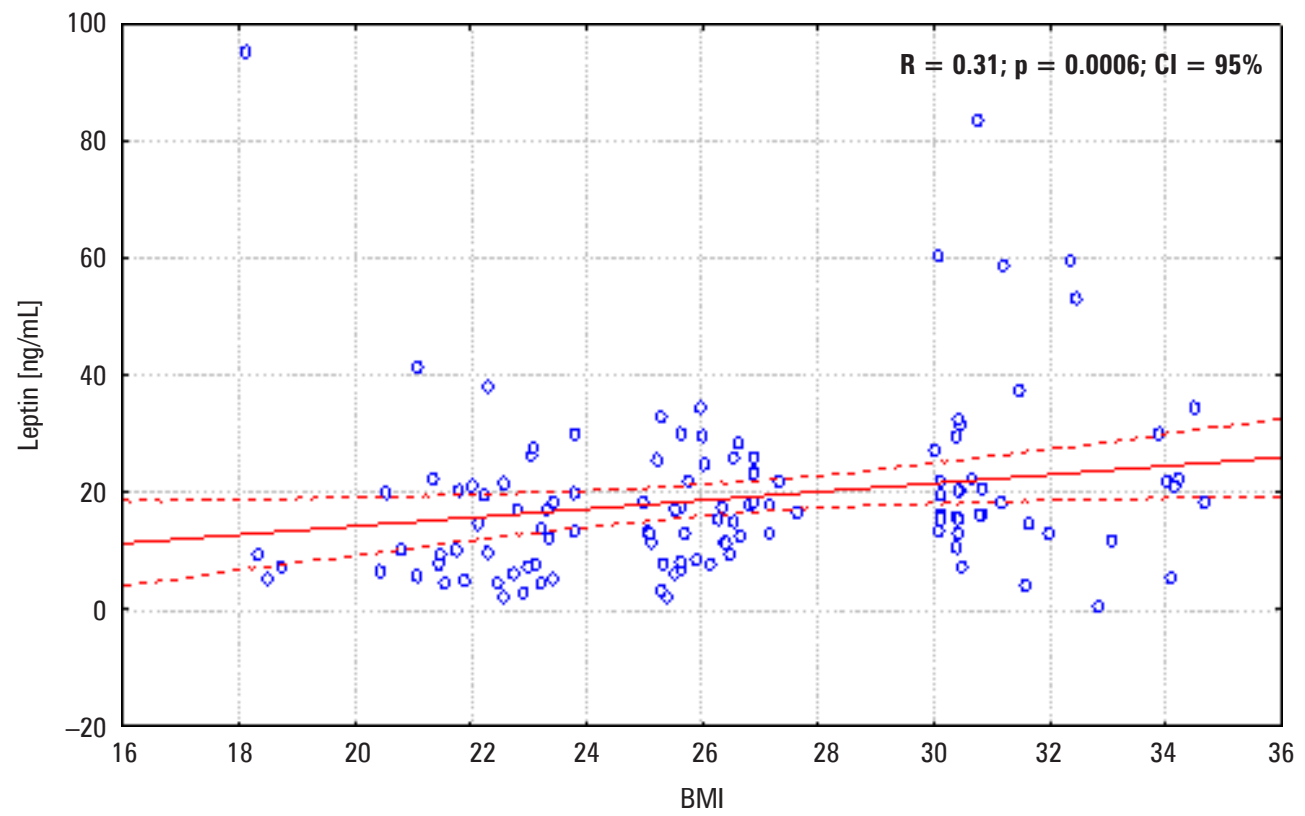

Figure 1. Correlations between leptin levels and body mass index (BMI) in postmenopausal women with osteoporosis

Table III. Analysis of correlation between adipocytokines, bone mineral density (BMD), and body mass index (BMI) in the obese group

\begin{tabular}{lccc}
\hline Pair of variables & N & r-Spearman & p \\
\hline Leptin $[\mathrm{ng} / \mathrm{mL}]$ \& BMI & 40 & 0.00 & 0.9899 \\
\hline Leptin $[\mathrm{ng} / \mathrm{mL}]$ \& BMD & 40 & -0.09 & 0.5852 \\
\hline Leptin $[\mathrm{ng} / \mathrm{mL}]$ \& adipo $[\mu \mathrm{g} / \mathrm{mL}]$ & 40 & 0.13 & 0.4129 \\
\hline Leptin $[\mathrm{ng} / \mathrm{mL}]$ \& resistin $[\mathrm{ng} / \mathrm{mL}]$ & 40 & 0.04 & 0.8244 \\
\hline Adipo $[\mu \mathrm{g} / \mathrm{mL}]$ \& BMI & 40 & 0.25 & 0.1140 \\
\hline Adipo $[\mu \mathrm{g} / \mathrm{mL}]$ \& BMD & 40 & -0.26 & 0.1024 \\
\hline Adipo $[\mu \mathrm{g} / \mathrm{mL}]$ \& leptin $[\mathrm{ng} / \mathrm{mL}]$ & 40 & 0.13 & 0.4129 \\
\hline Adipo $[\mu \mathrm{g} / \mathrm{mL}]$ \& resistin $[\mathrm{ng} / \mathrm{mL}]$ & 40 & -0.34 & 0.0325 \\
\hline Resistin $[\mathrm{ng} / \mathrm{mL}]$ \& BMI & 40 & 0.04 & 0.8127 \\
\hline Resistin $[\mathrm{ng} / \mathrm{mL}]$ \& BMD & 40 & 0.27 & 0.0926 \\
\hline Resistin $[\mathrm{ng} / \mathrm{mL}]$ \& leptin $[\mathrm{ng} / \mathrm{mL}]$ & 40 & 0.04 & 0.8244 \\
\hline Resistin $[\mathrm{ng} / \mathrm{mL}]$ \& adipo $[\mu \mathrm{g} / \mathrm{mL}]$ & 40 & -0.34 & 0.0325 \\
\hline
\end{tabular}

in obese women compared to normoweight women was demonstrated $[8,32]$. Lecke et al. suggested that the changes in leptin and/or adiponectin concentration may be an individual feature [33]. The study demonstrated that the average leptin concentration was highest in the group of obese postmenopausal women and was statistically significant compared to the group of women with normal BMI, in which the level of this adipocytokine was lower. This paper has demonstrated a positive, statistically significant relationship between leptin and the BMI for the whole population of the postmenopausal women with osteoporosis. The
Table IV. Analysis of correlations between adipocytokines, (BMD), and body mass index (BMI) in the group with normal $B M I$

\begin{tabular}{lccc}
\hline Pair of variables & N & r-Spearman & p \\
\hline Leptin $[\mathrm{ng} / \mathrm{mL}]$ \& adipo $[\mu \mathrm{g} / \mathrm{mL}]$ & 40 & -0.46 & 0.0027 \\
\hline Leptin $[\mathrm{ng} / \mathrm{mL}]$ \& resistin $[\mathrm{ng} / \mathrm{mL}]$ & 40 & 0.24 & 0.1346 \\
\hline Leptin $[\mathrm{ng} / \mathrm{mL}]$ \& BMI & 40 & 0.06 & 0.7064 \\
\hline Leptin $[\mathrm{ng} / \mathrm{mL}]$ \& BMD & 40 & 0.13 & 0.4149 \\
\hline Adipo $[\mu \mathrm{g} / \mathrm{mL}]$ \& leptin $[\mathrm{ng} / \mathrm{mL}]$ & 40 & -0.46 & 0.0027 \\
\hline Adipo $[\mu \mathrm{g} / \mathrm{mL}]$ \& resistin $[\mathrm{ng} / \mathrm{mL}]$ & 40 & -0.33 & 0.0379 \\
\hline Adipo $[\mu \mathrm{g} / \mathrm{mL}]$ \& BMI & 40 & 0.02 & 0.8912 \\
\hline Adipo $[\mu \mathrm{g} / \mathrm{mL}]$ \& BMD & 40 & 0.11 & 0.4933 \\
\hline Resistin $[\mathrm{ng} / \mathrm{mL}]$ \& leptin $[\mathrm{ng} / \mathrm{mL}]$ & 40 & 0.24 & 0.1346 \\
\hline Resistin $[\mathrm{ng} / \mathrm{mL}]$ \& adipo $[\mu \mathrm{g} / \mathrm{mL}]$ & 40 & -0.33 & 0.0379 \\
\hline Resistin $[\mathrm{ng} / \mathrm{mL}]$ \& BMl & 40 & 0.06 & 0.7009 \\
\hline Resistin $[\mathrm{ng} / \mathrm{mL}]$ \& BMD & 40 & 0.07 & 0.6668 \\
\hline
\end{tabular}

higher results for the whole group obtained in the study depend most probably on hormonal changes occurring after menopause [34]. It seems that body weight has the greatest influence on the secretion of leptin. The paper has also demonstrated a significant, positive relationship between obesity and BMD; as BMD increases in the population of the investigated postmenopausal women with osteoporosis, the BMI increases as well, which may contribute to the intensification of osteoporosis.

The highest concentration of adiponectin among the groups was found in the group with normal BMI. 
The group of obese women demonstrated lower concentrations, but no statistically significant difference was demonstrated. Not all studies demonstrated changes in adiponectin secretion in postmenopausal women [35]. It was probably because of non-homogeneous groups with differences in age, count, BMI, or distribution of the adipose tissue. Some researchers reported a negative correlation between adiponectin and BMD. A meta-analysis confirmed a reverse correlation, which may be due to the effect of race, abusive substances, and metabolic diseases on its concentration [7]. This would be in support of disparate results of studies by Sodi et al., who investigated a group of healthy women with osteoporosis. They identified a negative correlation between the concentration of adiponectin and BMI without any difference between groups with and without osteoporosis. The total concentration of adiponectin decreased in obese women with the normalisation of the BMI [36]. Zoico et al. demonstrated a negative correlation between body weight and BMD regarding the femoral neck in postmenopausal women as well, which suggest a possible effect of adiponectin on bone metabolism independently of the BMI [37]. According to Morcow, adiponectin was negatively correlated with the BMI and BMD, but the study group was not homogeneous because it included women before and after menopause [10].

Some reports claim no relationship between adiponectin and bone mineral density regardless of the site of measurement. [38]. A study by Liu et al. and another one by Cnop demonstrated a lack of correlation of adiponectin with BMD in women before and after menopause [7, 39]. This analysis did not demonstrate any dependence between BMD and adiponectin in neither of the groups of postmenopausal women with osteoporosis. According to Jurime, there is a positive correlation between adiponectin and BMD in the L2-L4 section of the spine and bone mineral content. The essence of the study was the finding that adiponectin may affect BMD through the BMI, WHR, and body weight. [40] A study by Wu confirmed a positive correlation of adiponectin with bone formation markers only in postmenopausal women, which supported a proposal that it may take part in bone resorption and that menopause may affect the above-mentioned processes [41]. Not all researchers concur in these observations [36]. Tenta et al. demonstrated that adiponectin may be an independent factor affecting bone metabolism and BMD. The study involved, however, non-homogeneous groups, the larger one involved patients with osteopaenia, and the smaller one, patients with osteoporosis. The authors did not assess the impact of the BMI [42]. According to Jurimae et al., adiponectin is responsible for bone mass density in humans in as much or as little as 3-12\% [40].

The effect of age on the secretion of adiponectin was suggested because the adiponectin level was shown to increase with age $[39,43]$. The mass of adipose tissue did not demonstrate any influence on the secretion of the substance [39]. A study by Ryan et al. on postmenopausal women did not demonstrate any changes in adiponectin secretion with age in relation to the BMI [44]. The present study did not identify any impact of age on the secretion of adiponectin, which may be due to the homogeneity of the group of postmenopausal women with osteoporosis.

Data on resistin are scarce. Its high concentrations may be a manifestation of insulin resistance [45]. Resistin concentrations in all groups in the present paper were similar. The obese group demonstrated a lower concentration of resistin. The normoweight group had a slightly higher average concentration. Literature data indicate higher concentrations of resistin in obese people $[11,46]$, but the study involved people not suffering from osteoporosis. This paper did not identify any correlation between BMD and resistin in either of the groups.

To sum up, the study confirmed higher leptin concentrations in obese postmenopausal women with osteoporosis. The secretion of leptin is positively correlated with the body mass index. It was also demonstrated that BMD increases with growing BMI. No effect of obesity on the secretion of adiponectin or resistin in women with postmenopausal osteoporosis was found. From among the investigated adipocytokines, only leptin can be considered a bone tissue protective factor in postmenopausal women.

\section{References}

1. Compston J, Cooper A, Cooper C, et al. National Osteoporosis Guideline Group (NOGG). Guidelines for the diagnosis and management of osteoporosis in postmenopausal women and men from the age of 50 years in the UK. Maturitas. 2009; 62(2): 105-108, doi: 10.1016/j.maturitas.2008.11.022, indexed in Pubmed: 19135323.

2. Albright F, Smith PH, Richardson AM. Postmenopausal osteoporosis - its clinical features. J Am Med Assoc. 1941; 116: 2465-2474, doi: 10.1001/jama.1941.02820220007002.

3. Zeng J, Li K, Gong Y, et al. Association of pro-inflammatory cytokines with QCT-measured bone mineral density and its gender difference in a Chinese population - a pilot study. Endokrynol Pol. 2019; 70(3): 248-254, doi: 10.5603/EP.a2019.0014, indexed in Pubmed: 30845341.

4. Kanis JA, Johnell O, Oden A, et al. Long-term risk of osteoporotic fracture in Malmö. Osteoporos Int. 2000; 11(8): 669-674, doi: 10.1007/s001980070064, indexed in Pubmed: 11095169.

5. Oursler MJ, Landers JP, Riggs BL, et al. Oestrogen effects on osteoblasts and osteoclasts. Ann Med. 1993; 25(4): 361-371, doi: 10.3109/07853899309147298, indexed in Pubmed: 8217102.

6. Ravn P, Cizza G, Bjarnason NH, et al. Low body mass index is an important risk factor for low bone mass and increased bone loss in early postmenopausal women. Early Postmenopausal Intervention Cohort (EPIC) study group. J Bone Miner Res. 1999; 14(9): 1622-1627, doi: 10.1359/jbmr.1999.14.9.1622, indexed in Pubmed: 10469292.

7. Liu Y, Song CY, Wu SS, et al. Novel adipokines and bone metabolism. Int J Endocrinol. 2013; 2013: 895045, doi: 10.1155/2013/895045, indexed in Pubmed: 23431296. 
8. Reid IR. Fat and bone. Arch Biochem Biophys. 2010; 503(1): 20-27, doi: 10.1016/j.abb.2010.06.027, indexed in Pubmed: 20599663.

9. Albala C, Yauez M, Deroto E, et al. Obesity as a protective factor for postmenopausal osteoporosis. Int J Obes Relat Metab Disord. 1996; 20(11): 1027-1032, indexed in Pubmed: 8923160.

10. Morcov C, Vulpoi C, Branisteanu D. Correlation between adiponectin, leptin, insulin-like growth factor- 1 and bone mineral density in pre and post-menopausal women. Rev Med Chir Soc Med Nat Iasi. 2012; 116(3): 785-789, indexed in Pubmed: 23272528.

11. Al-Suhaimi EA, Shehzad A. Leptin, resistin and visfatin: the missing link between endocrine metabolic disorders and immunity. Eur J Med Res. 2013; 18: 12, doi: 10.1186/2047-783X-18-12, indexed in Pubmed: 23634778.

12. Biver E, Salliot $C$, Combescure $C$, et al. Influence of adipokines and ghrelin on bone mineral density and fracture risk: a systematic review and meta-analysis. J Clin Endocrinol Metab. 2011; 96(9): 2703-2713, doi: 10.1210/jc.2011-0047, indexed in Pubmed: 21778223.

13. Hsu YH, Venners SA, Terwedow HA, et al. Relation of body composition, fat mass, and serum lipids to osteoporotic fractures and bone mineral density in Chinese men and women. Am J Clin Nutr. 2006; 83(1): 146-154, doi: 10.1093/ajcn/83.1.146, indexed in Pubmed: 16400063.

14. Siemińska L, Cichoń-Lenart A, Kajdaniuk D, et al. Hormony płciowe i adipocytokiny u kobiet po menopauzie. Pol Merk Lek. 2006; XX(120): 727-729.

15. Cornish J, Callon KE, Bava U, et al. Leptin directly regulates bone cell function in vitro and reduces bone fragility in vivo. J Endocrinol. 2002; 175(2): 405-415, doi: 10.1677/joe.0.1750405, indexed in Pubmed: 12429038.

16. Ben-Eliezer M, Phillip M, Gat-Yablonski G. Leptin regulates chondrogenic differentiation in ATDC5 cell-line through JAK/STAT and MAPK pathways. Endocrine. 2007; 32(2): 235-244, doi: 10.1007/s12020-007-9025-y, indexed in Pubmed: 18080100.

17. Thomas T, Gori F, Khosla S, et al. Leptin acts on human marrow stromal cells to enhance differentiation to osteoblasts and to inhibit differentiation to adipocytes. Endocrinology. 1999; 140(4): 1630-1638, doi: 10.1210/endo.140.4.6637, indexed in Pubmed: 10098497.

18. Leibel RL. The role of leptin in the control of body weight. Nutr Rev. 2002; 60(10 Pt 2): S15-S9; discussion S68, doi: 10.1301/002966402320634 788, indexed in Pubmed: 12403079.

19. Holloway WR, Collier FM, Aitken CJ, et al. Leptin inhibits osteoclast generation. J Bone Miner Res. 2002; 17(2): 200-209, doi: 10.1359/jbmr.2002.17.2.200, indexed in Pubmed: 11811550.

20. Silha JV, Krsek M, Skrha JV, et al. Plasma resistin, adiponectin and leptin levels in lean and obese subjects: correlations with insulin resistance. Eur J Endocrinol. 2003; 149(4): 331-335, doi: 10.1530/eje.0.1490331, indexed in Pubmed: 14514348.

21. Horakova D, Stepanek L, Nagelova R, et al. Total and high-molecular-weight adiponectin levels and prediction of insulin resistance. Endokrynol Pol. 2018; 69(4): 375-380, doi: 10.5603/EP.a2018.0035, indexed in Pubmed: 29952412.

22. Luo XH, Guo LJ, Xie H, et al. Adiponectin stimulates RANKL and inhibit OPG expression in human osteoblasts through the MAPK signaling pathway. J Bone Miner Res. 2006; 21(10): 1648-1656, doi: 10.1359/jbmr.060707, indexed in Pubmed: 16995820.

23. Berner HS, Lyngstadaas SP, Spahr A, et al. Adiponectin and its receptors are expressed in bone-forming cells. Bone. 2004; 35(4): 842-849, doi: 10.1016/j.bone.2004.06.008, indexed in Pubmed: 15454091.

24. Lee $\mathrm{WY}$, Rhee EJ, Oh KiW, et al. Identification of adiponectin and its receptors in human osteoblast-like cells and association of T45C polymorphism in exon 2 of adiponectin gene with lumbar spine bone mineral density in Korean women. Clin Endocrinol (Oxf). 2006; 65(5): 631-637, doi: 10.1111/j.1365-2265.2006.02641.x, indexed in Pubmed: 17054465 .

25. Gomez R, Lago F, Gomez-Reino J, et al. Adipokines in the skeleton: influence on cartilage function and joint degenerative diseases. J Mol Endocrinol. 2009; 43(1): 11-18, doi: 10.1677/JME-08-0131, indexed in Pubmed: 19240195.

26. Douchi T, Yamamoto S, Oki T, et al. Difference in the effect of adiposity on bone density between pre- and postmenopausal women. Maturitas. 2000; 34(3): 261-266, doi: 10.1016/s0378-5122(99)00114-0, indexed in Pubmed: 10717492.
27. Tenta R, Kontogianni MD, Yiannakouris N. Association between circulating levels of adiponectin and indices of bone mass and bone metabolism in middle-aged post-menopausal women. J Endocrinol Invest. 2012; 35(3): 306-311, doi: 10.3275/7744, indexed in Pubmed: 21606670.

28. Silva HG, Mendonça LMC, Conceição FL, et al. Influence of obesity on bone density in postmenopausal women. Arq Bras Endocrinol Metabol. 2007; 51(6): 943-949, doi: 10.1590/s0004-27302007000600008, indexed in Pubmed: 17934661.

29. Reid IR. Obesity and osteoporosis. Ann Endocrinol. 2006; 67: 125-129, doi: 10.1016/S0003-4266(06)72567-7, indexed in Pubmed: 16639362

30. Rosen CJ, Bouxsein ML. Mechanisms of disease: is osteoporosis the obesity of bone? Nat Clin Pract Rheumatol. 2006; 2(1): 35-43, doi: 10.1038/ncprheum0070, indexed in Pubmed: 16932650.

31. Rosen CJ. Osteoporoza. Zasady rozpoznawania i leczenia. Springer PWN, Warszawa 1998: 16-22.

32. Blain H, Vuillemin A, Guillemin F, et al. Serum leptin level is a predictor of bone mineral density in postmenopausal women. J Clin Endocrinol Metab. 2002; 87(3): 1030-1035, doi: 10.1210/jcem.87.3.8313, indexed in Pubmed: 11889157

33. Lecke SB, Morsch DM, Spritzer PM. Leptin and adiponectin in the female life course. Braz J Med Biol Res. 2011; 44(5): 381-387, indexed in Pubmed: 21445529.

34. Ostlund RE, Yang JW, Klein S, et al. Relation between plasma leptin concentration and body fat, gender, diet, age, and metabolic covariates. J Clin Endocrinol Metab. 1996; 81(11): 3909-3913, doi: 10.1210/jcem.81.11.8923837, indexed in Pubmed: 8923837.

35. Bokarewa M, Nagaev I, Dahlberg L, et al. Resistin, an adipokine with potent proinflammatory properties. J Immunol. 2005; 174(9): 5789-5795, doi: 10.4049/jimmunol.174.9.5789, indexed in Pubmed: 15843582.

36. Sodi R, Hazell MJ, Durham BH, et al. The circulating concentration and ratio of total and high molecular weight adiponectin in post-menopausal women with and without osteoporosis and its association with body mass index and biochemical markers of bone metabolism. Clin Biochem. 2009; 42(13-14): 1375-1380, doi: 10.1016/j.clinbiochem.2009.06.003, indexed in Pubmed: 19523465.

37. Zoico E, Zamboni M, Bosello O. The consequences of aging on endocrine function of adipose tissue. Obes Metab. 2008; 4(1): 64-75.

38. Kontogianni MD, Dafni UG, Routsias JG, et al. Blood leptin and adiponectin as possible mediators of the relation between fat mass and BMD in perimenopausal women. J Bone Miner Res. 2004; 19(4): 546-551 doi: 10.1359/JBMR.040107, indexed in Pubmed: 15005840.

39. Cnop M, Havel PJ, Utzschneider KM, et al. Relationship of adiponectin to body fat distribution, insulin sensitivity and plasma lipoproteins: evidence for independent roles of age and sex. Diabetologia. 2003; 46(4): 459-469, doi: 10.1007/s00125-003-1074-z, indexed in Pubmed: 12687327.

40. Jürimäe J, Jürimäe T. Adiponectin is a predictor of bone mineral density in middle-aged premenopausal women. Osteoporos Int. 2007; 18(9): 1253-1259 doi: 10.1007/s00198-007-0365-5, indexed in Pubmed: 17396209.

41. Wu F, Ames R, Clearwater J, et al. Prospective 10-year study of the determinants of bone density and bone loss in normal postmenopausal women, including the effect of hormone replacement therapy. Clin Endocrinol (Oxf). 2002; 56(6): 703-711, doi: 10.1046/j.1365-2265.2002.01 534.x, indexed in Pubmed: 12072039.

42. Tenta R, Kontogianni MD, Yiannakouris N. Association between circulating levels of adiponectin and indices of bone mass and bone metabolism in middle-aged post-menopausal women. J Endocrinol Invest. 2012; 35(3): 306-311, doi: 10.3275/7744, indexed in Pubmed: 21606670.

43. Laughlin GA, Barrett-Connor E, May S. Sex-specific determinants of serum adiponectin in older adults: the role of endogenous sex hormones. Int J Obes (Lond). 2007; 31(3): 457-465, doi: 10.1038/sj.ijo.0803427, indexed in Pubmed: 16819528.

44. Ryan AS, Berman DM, Nicklas BJ, et al. Plasma adiponectin and leptin levels, body composition, and glucose utilization in adult women with wide ranges of age and obesity. Diabetes Care. 2003; 26(8): 2383-2388, doi: 10.2337/diacare.26.8.2383, indexed in Pubmed: 12882866.

45. Steppan CM, Bailey ST, Bhat S, et al. The hormone resistin links obesity to diabetes. Nature. 2001; 409(6818): 307-312, doi: 10.1038/35053000, indexed in Pubmed: 11201732

46. Rea R, Donnelly R. Resistin: an adipocyte-derived hormone. Has it a role in diabetes and obesity? Diabetes Obes Metab. 2004; 6(3): 163-170, doi: 1 0.1111/j.1462-8902.2004.00334.x, indexed in Pubmed: 15056123. 